\title{
How Forest Biodiversity rather than Desertification Can Endanger Some Vulture
}

\section{Species}

\section{O'Neal Campbell M*}

Environmental Scientist, Lakehead University, Ontario, Canada

*Corresponding author: O'Neal Campbell M, Environmental Scientist, Lakehead University, Ontario, Canada, Tel: 2502203434; E-mail: ecol55@hotmail.com

Rec date: August 3, 2014; Acc date: August 5, 2014; Pub date: August 9, 2014

Copyright: (c) 2014 O'Neal Campbell M. This is an open-access article distributed under the terms of the Creative Commons Attribution License, which permits unrestricted use, distribution, and reproduction in any medium, provided the original author and source are credited.

\section{Introduction}

Vultures are currently recorded as icons of conservation, biodiversity and political ecology, due to the diclofenac epidemic in Asia; the urban invasion of North American cities by Black and Turkey Vultures; and the reintroduction of California Condors into the previous habitats [1-8]. Resultant actions, acknowledgements and plans for vulture conservation exist in Europe (mainly concerning the rare Griffon and Cinereous Vultures), Asia (mainly concerning the Gyps Griffon Vultures), the Americas (mainly concerning the Andean Condor); and more widely on different types of vulture health problems [9-15]. A relevant question is; does higher ecosystem biodiversity contribute to increased vulture presence? As a partial answer to this complex question, vulture habitation in two biomes of maximum and minimum biodiversity; the forest and the desert is examined.

\section{Forests and Deserts as Vulture Habitats}

Biome biodiversity is fundamental to species presence; here a biome is a region of similar climatic conditions with associated communities of animals and plants (the World Wide Fund for Nature (WWF) recognises such 14 biomes) [16]. Three 'opposite' biomes (based on biodiversity) are Biomes 1 and 2 (Tropical and subtropical moist dry broadleaf forests) and Biome 13 (the deserts and xeric shrublands). A biodiversity based hypothesis assumes that vultures would be more common in highly biodiverse forest than in the sparse xeric shrublands and especially deserts. However, many vultures avoid forests; prefering Biomes 7,8 and 10 (savannas, shrublands and grasslands, of the tropical/subtropical, temperate and mountain mountain regions respectively).

Excepting the three Cathartes species (Turkey, Greater Yellowheaded and Lesser-headed Vultures), all the other twenty species of New World and Old World vultures hunt by sight rather than smell. The sensory abilities of vultures is long debated [17-32]. Consequently, the non Carthartes species are rare in forests, unable to visually penetrate the canopy to trace carrion on the forest floor. Large animals are also generally rarer in forest than savanna. Hence, the "forested areas of Africa or Asia do not support scavenging birds, while neotropical forest is the center of distribution for the cathartid vultures" [33].

Carthartes vultures fly low just above the forest canopy, descending only when food is scented; Turkey Vultures have located hidden carrion easily [33]. "Black Vultures do not have a sense of smell, and my observations in other study areas have shown that they are not found in undisturbed forest and cannot locate food in forest conditions unless led there by Turkey Vultures" [33-36]. The GreaterYellow-headed Vulture, often named the "forest vulture" to distinguish it from the Yellow-headed Vulture or "savanna vulture" forages in forests [37]. It has been recorded to locate $63 \%$ of provided carcasses in dense forest, while mammalian scavengers found only $5 \%$ [29].

The deserts, semi-deserts and xeric shrublands are at least as important as the forest for vultures, hence dsertification may not necessarily destroy vulture populations. Desertification, the final stage of deforestation, is defined as land degradation from water, soil and biodiversity decline from drought or improper/inappropriate agriculture [38]. Vultures in deserts track cattle-herding and/or camel driving activities, or seasonal migration of ungulates. In the Saharan and Sahelian habitats of Africa, Egyptian, Hooded, White-backed, Rüppell's Vulture, Lappet-faced and White-headed Vultures subsist on livestock, (camels, cattle, donkeys, and horses) and rarer gazelles, these migrating for grazing and seasonal rain [39]. All these vultures are rare or absent from the African forest [40]. In the New World, Turkey and Black Vultures frequent deserts and semi-deserts in California, Arizona, New Mexico, Nevada and "are probably the most abundant avian scavengers in semi-arid shrublands" of central Mexico [41] and northern Mexico [42].

\section{Conclusions}

Crucially, sparsely vegetated landcover must be assessed further for vulture habitation. Reforestation, the commonest form of biodiversity conservation, may actually endanger some vulture species without a sense of smell. The Carthartes Vultures must be distinguished from the rest in this regard. Vultures are a feeding clade that generally require open landcover, therefore making a possibly unique case for their inclusion in studies of biodiversity and endangered species.

\section{References}

1. DeVault TL, Reinhart BD, Brisbin IL, Rhodes OE (2005) Flight behavior of black and turkey vultures: implications for reducing bird-aircraft collisions. Journal of Wildlife Management 69: 592-599.

2. Blackwell BF, Wright SE (2006) Collisions of Red-tailed Hawks (Buteo jamaicensis), Turkey Vultures (Cathartes aura), and Black Vultures (Coragyps atratus) with aircraft: implications for bird strike reduction. Journal of Raptor Research 40: 76-80.

3. Hunt W, Parish C, Farry S, Lord T, Sieg R, et al., (2007) Movements of introduced California condors in Arizona in relation to lead exposure. California condors in the $21^{\text {st }}$ century. Series in Ornithology No. 2: 79-96. Nuttall American Ornithologists' Union and Nuttall Ornithological Club.

4. Mee A, Rideout B A, Hamber JA, Todd JN, Austin G, et al., (2007) Junk ingestion and nestling mortality in a reintroduced population of California Condors Gymnogyps californianus. Bird Conservation International 17: 1-13.

5. Woodford MH, Bowden CGR, Shah N (2008) Diclofenac in Asia and Africa - repeating the same mistake? Harmonisation and improvement 
of registration and quality control of Veterinary Medicinal Products in Africa. OIE World Organisation for Animal Health, Paris.

6. Margalida A, Donazar JA, Carrete M, Sanchezzapata JA (2010) Sanitary versus environmental policies: fitting together two pieces of the puzzle of European vulture conservation. Journal of Applied Ecology 47: 931-935.

7. Moreno-Opo R, Arredondo A, Guil F (2010) Foraging range and diet of Cinereous Vulture Aegypius monachus using livestock resources in central Spain. Ardeola 57: 111-119.

8. Austin W, Day K, Gatto A, Humphrey J, Parish C, et al., (2012) A Review of the Third Five Years of the California Condor Reintroduction Program in the Southwest (2007-2011). Arizona Ecological Services Office, Phoenix.13. Lieberman A, Rodriguez JV, Paez JME, Wiley J (1993) The reintroduction of the Andean condor into Colombia, South America: 1989-1991. Oryx, 27: 83-90.

9. Lieberman A, Rodriguez JV, Paez JME, Wiley J (1993) The reintroduction of the Andean condor into Colombia, South America: 1989-1991. Oryx, 27: 83-90.

10. Gilbert M, Watson RT, Virani MZ, Oaks JL, Ahmed S, et al., (2006) Rapid population declines and mortality clusters in three Oriental Whitebacked Vulture Gyps bengalensis colonies in Pakistan due to diclofenac poisoning. Oryx 40: 388-399.

11. Cade TJ (2007) Exposure of California Condors to lead from spent ammunition. Journal of Wildlife Management 71: 2125-2133.

12. Prakash V, Green RE, Pain DJ, Ranade SP, Saravanan S, et al., (2007) Recent changes in populations of resident Gyps vultures in India. Journal of the Bombay Natural History Society 104: 127-133.

13. Sorenson K, Burnett J, Mee A, Hall L (2007) Lead concentrations in the blood of Big Sur California condors. California condors in the $21 \mathrm{st}$ century. Series in Ornithology No. 2: 185-195. Nuttall Ornithological Club and American Ornithologists' Union, Cambridge, MA.

14. Botha AJ, Ogada DL, Virani MZ (2012) Pan-African vulture summit 2012, April 16-20, 2012, Masai Mara, Kenya. Wildlife without Borders, SASOL, Endangered Wildlife Trust, and The Peregrine Fund, Modderfontein, South Africa

15. Salisbury C (2013) 600 vultures killed by elephant poachers in Namibia.

16. Olson DM, Dinerstein E, Wikramanayake EM, Burgess ND, Powell GVN, et al., (2001) Terrestrial Ecoregions of the World: A New Map of Life on Earth, BioScience 51: 933-938.

17. Sayles I (1887) The sense of smell in Cathartes aura. Auk 4:173-174.

18. Hoxie W (1887) Sense of smell in the Black Vulture. Ornithologist and Oologist 12:132.

19. Sayles I (1887) The sense of smell in Cathartes aura. Auk 4:51-56.

20. Lewis JB (1928) Sight and scent in the Turkey Vulture. Auk 45:467-470

21. Earl TM (1929) On the scent of vultures. Wilson Bulletin 41:103.

22. Darlington PJ Jr. (1930) Notes on the senses of vultures. Auk 47:251-252.

23. Vogt W (1941) Food detection by vultures and condors. Auk 58:571.

24. Owre OT, Northington PO (1961) Indication of the sense of smell in the Turkey Vulture, Cathartes aura (Linnaeus), from feeding tests. American Midland Naturalist 66: 200-105.
25. Stager KE (1964) The role of olfaction in food location by the Turkey Vulture and other cathartids. Los Angeles County Museum Contributions in Science 81: 1-63.

26. Fischer AB (1969) Laboratory experiments on and open-country observations of the visual acuity and behavior of Old World vultures. Zoologische Jahrbücher Systematik 96: 81-132.

27. Bang BG (1972) The nasal organs of the Black and Turkey Vultures: a comparative study of the cathartid species Coragyps atratus atratus and Cathartes aura septentrionalis (with notes on Cathartes aura falklandica, Pseudogyps bengalensis, and Neophron percnopterus. Journal of Morphology 115: 153-184.

28. Graves GR (1992) Greater Yellow-headed Vulture (Cathartes melambrotus) locates food by olfaction. Journal of Raptor Research 26: 38-39.

29. Gomez LG, Houston DC, Cotton P, Tye A, Luis G, Houston DC, Cotton P, Tye A (1994) The role of greater yellow-headed vultures Cathartes melambrotus as scavengers in neotropical forest. Ibis 136: 193-196.

30. Smith HRR, DeGraaf M, Miller RS (2002) Exhumation of food by Turkey Vultures. Journal of Raptor Research 36: 144-145

31. Ristow D (2003) Can the sense of smell in the Turkey Vulture be put to any conservation use? International Hawkwatcher 7: 18-19.

32. Gilbert M, Chansocheat S (2006) Olfaction in accipitrid vultures. Vulture News 55: 6-7.

33. Houston DC (1986) Scavenging effciency of Turkey Vultures in tropical forest. The Condor 88: 318-323.

34. Wallace MP, Temple SA (1987) Competitive interactions within and between species in a guild of avian scavengers. Auk 104: 290-295.

35. Houston DC (1988) Competition for food between Neotropical vultures in forest. Ibis 130: 402-417.

36. Buckley NJ (1996) Food finding and the influence of information, local enhancement, and communal roosting on foraging success of North American vultures. Auk 113: 473-488.

37. Robinson SK (1994) Habitat selection and foraging ecology of raptors in Amazonian Peru. Biotropica 26: 443-458.

38. Geist HJB (2005) The causes and progression of desertification. Ashgate Publishing Ltd, Farnham.

39. Wacher T, Newby J, Houdou I, Harouna A, Rabeil T (2013) Vulture observations in the Sahelian zones of Chad and Niger. Bull ABC 20: 186-199.

40. Campbell M (2009) Factors for the presence of avian scavengers in Accra and Kumasi, Ghana. Area 41: 341-349.

41. Dean WRJ, Yeaton RI, Milton, SJ (2006) Foraging sites of Turkey Vultures and Common Ravens Corvus corax in central Mexico. Vulture News 54: 30-33.

42. Hiraldo F, Delibes M, Donazar JA (1991) Comparison of diets of Turkey Vultures in three regions of northern Mexico. Journal of Field Ornithology 62: 319-324. 